Qasim Abbood Mahdi

AL Taff University College Iraq, Karbala, Iraq

\title{
THE METHOD OF INCREASING THE IMMUNITY OF COMMUNICATION SYSTEMS
}

\begin{abstract}
Nowadays, due to a severe shortage of radio resources of communication systems, which is caused by an increase in the number of subscribers of cellular communication systems, an increase in demand for information resources, which in turn leads to the search for new technological approaches to its solution. The analysis of well-known scientific works carried out in the article showed that the technology of orthogonal frequency multiplexing almost completely exhausted the possibility of its improvement. One of the ways to improve the efficiency of radio resource use of communication systems is using spectrally effective signals. This article has developed a methodology for improving the noise immunity of communication systems. The essence of this method is to switch the modes of communication in the session mode, depending on the signal-interference situation in the channel, with the subsequent adjustment of the parameters of the communication channel by selecting the optimal signal-code structures. In the course of the research, the main provisions of the theory of communication, the theory of signal-code structures, the theory of noise immunity, as well as general scientific methods such as analysis and synthesis were used. A distinctive feature of this method from the known, which determines its novelty are: the possibility of changing the mode of operation in the session mode; the modes of operation of this technique are signals with orthogonal frequency multiplexing and spectral-effective signals. The proposed technique provides $15-18 \%$ more noise immunity compared with the known methods of generating spectral-effective signals, but $10-12 \%$ less noise immunity compared to the orthogonal signals.
\end{abstract}

Keywords: communication system; radio resource; noise immunity; spectral-effective signals; orthogonal frequency multiplexing.

\section{Introduction}

Nowadays, the issue of increasing the efficiency of radio resource use of radio communication systems in the context of the acute shortage of the frequency resources is very important.

One of the ways to increase the efficiency of using the frequency range of communication equipment is the use of signals with orthogonal frequency multiplexing (OFDM). The signals from OFDM are very widely used in such systems as Wi-Fi, WiMAX, LTE, DVB-T2, DAB, DRM and in the downlink 4G LTE [1-3].

But nowadays, OFDM technology has actually exhausted its possibilities in terms of the possibility of improving technological efficiency [4].

Based on the above, multi-frequency signals with non-orthogonal compaction (Spectrally Efficient FDM signals) are considered as the most promising alternative to OFDM technology in these networks $[5,6]$.

Such signals are formed from OFDM signals by reducing the guard interval between subcarriers, thereby significantly increasing the spectral efficiency of signals $[1,2]$. Despite its significant advantages in terms of ensuring high spectral efficiency, the SEFDM technology has several disadvantages, namely [4]: high peak-factor and, as a result, significant under-utilization of output amplifiers for power; low noise immunity; nonlinear distortions in the radio path; synchronization errors.

Based on the above, goal of the article is a development of a methodology for improving the noise immunity of communication systems with SEFDM technology.

\section{Presentation of the main research material}

Let's consider the formation of SEFDM signals. From the analysis of sources $[5,6]$, it becomes clear that the main characteristic of SEFDM signals is the compression ratio: $a=\Delta f T=\Delta f / \Delta f_{\text {opt }}$, where $\Delta f_{\text {opt }}$ is the separation of frequency subcarriers in the frequency domain for orthogonal signals.

For OFDM signals, the $\alpha=1$ multiplication factor. SEFDM signals occupy a much smaller frequency band than OFDM signals, i.e. for $\Delta f<\Delta f_{\text {opt }}$ $\alpha<1$. is a compaction factor

For a $s_{N(i)}$ finite discrete signal, the corresponding expression from an $N$-sample FDM symbol is executed:

$$
S_{N}(i)=\frac{1}{N} \sum_{k=0}^{N-1} C_{N}(k) e^{j 2 \pi \frac{k_{i}}{N}}, i=1, \ldots,(N-1),
$$

where $C_{N}(k)$ are the manipulation symbols (in this case, $N$ indicates the length of the character). The signal is formed by the $N$-point inverse discrete Fourier transform (IDFT) from the $C_{N}(k)$ manipulation symbols (Fig. 1).

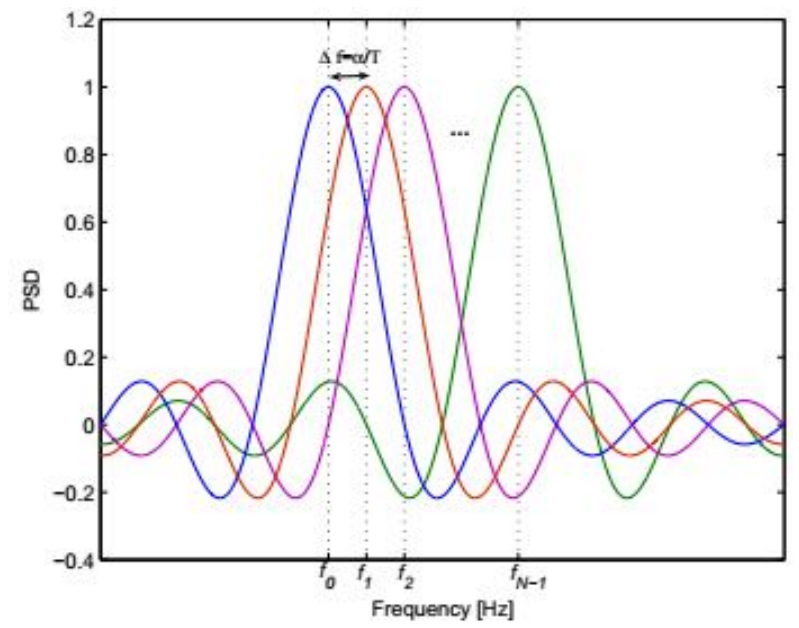

Fig. 1. SEFDM signal spectrum $[5,6]$ 
As it is indicated at the beginning of the article, the $P$ peak factor of the SEFDM signal is the ratio of the highest (peak) power to the average $P_{\text {aver }}$ of the $s(t)$ signal for the time duration of one $T$ symbol:

$$
\begin{gathered}
G=\max _{t \in[0 ; T]}\left\{|s(t)|^{2}\right\} / P_{\text {aver }}, \\
P_{\text {aver }}=\frac{1}{T} \int_{0}^{T}|s(t)|^{2} d t .
\end{gathered}
$$

The analysis of the influence of peak factors on communication systems with SEFDM technology was carried out in [7], but the influence of peak factors is taken into account without taking into account the influence of other destabilizing factors, such as intentional interference and signal fading.

All this leads to the development of methods for improving the noise immunity of communication systems with spectral-effective signals.

The method of improving the noise immunity of communication systems, the algorithm for the implementation of which is shown in Fig. 2, consists of the following steps.

1. An input of an initial data (action 1 in the Fig. 2). At this stage, the input data is entered, namely the parameters of the transmitting device and the $\Psi=\left\{\Psi_{i}\right\}$ communication channel, as well as the values of the permissible value of the probability of erroneous reception of $P_{\text {error prob }}$ signals, the minimum required $v_{i}$ дon information transfer rate, as well as the maximum peak pickup factor of the transmitting device.

2. Assessment of the communication channel state (step 2 in the Fig. 2).

At this stage, the state of the communication channel is assessed using the method of integrated assessment of the state of the communication channel based on the neural network. The essence of this method consists of estimating the state of the channel by several indicators, namely the probability of bit error, frequency and impulse characteristics of the communication channel [8]. Fig. 2).

3. Selection of the operation mode (steps 3-5 in the

I would like to draw attention to the fact that communication systems are characterized by two classical indicators of their evaluation, namely, $\beta_{E}$ energy and $\beta_{F}$ spectral efficiencies.

As it was mentioned earlier, the advantage of SEFDM signals over OFDM signals lies precisely in the

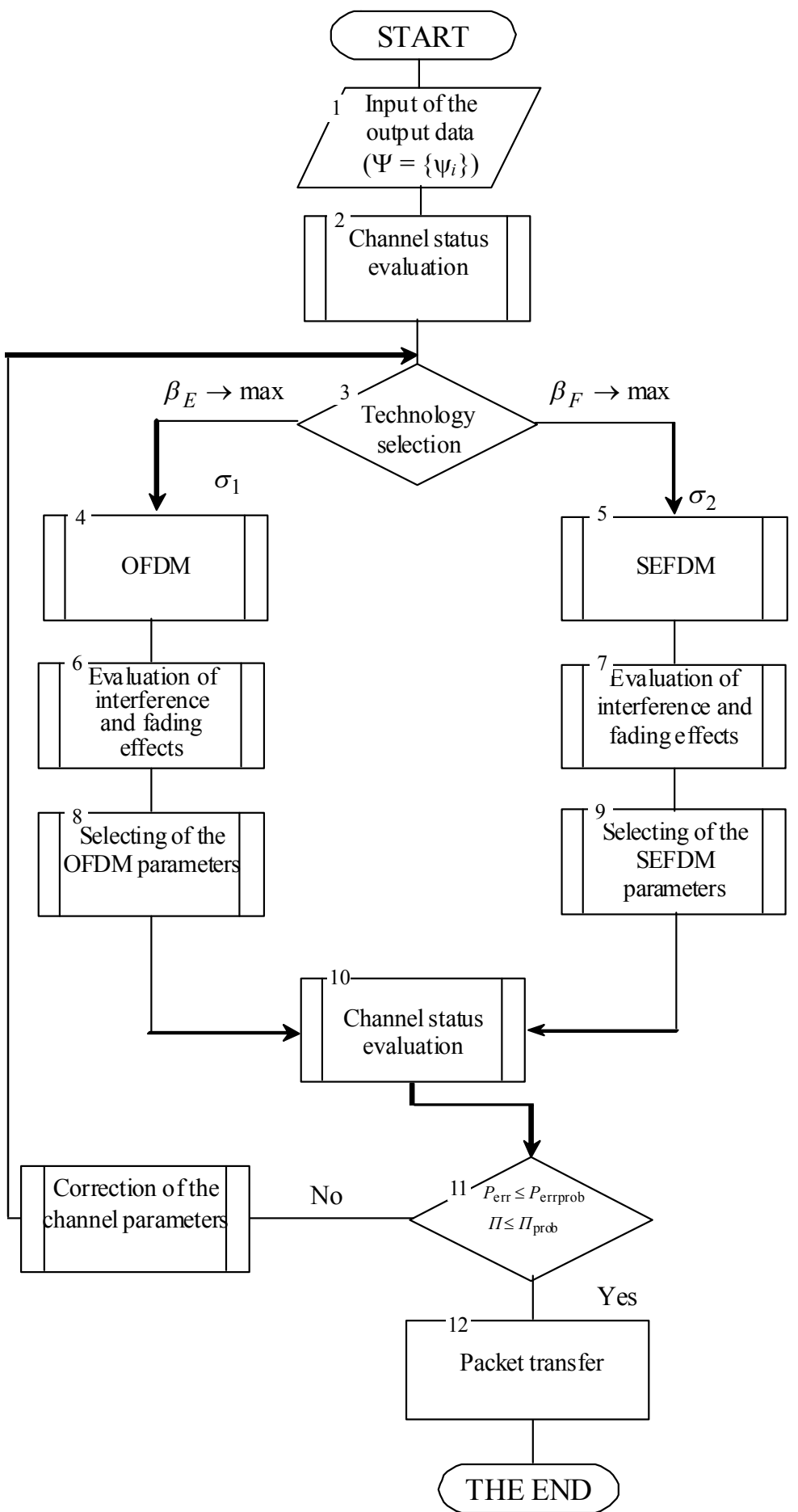

Fig. 2. Algorithm for the implementation of methods for improving the noise immunity of communication systems

$\beta_{F}$ increase, which in turn leads to a decrease in the energy of the $\beta_{E}$ communication channel (energy efficiency). The relationship of energy and spectral efficiencies induced in the formula [9]

$$
{ }^{B} E=\frac{{ }^{6} F}{2^{6} F-1} \text {. }
$$

From the source [9] it follows that this ratio is equally 1.443. Therefore, in this method it is proposed to change the operation modes of communication equipment from two options: OFDM signals and SEFDM 
signals, with subsequent correction of their parameters depending on the state of the communication channel.

The criterion for changing the mode of robots is the probability of a bit error in the $P_{\sigma}$ don communication channel.

In $[1,3,4,10]$, the research was conducted on the immunity of communication systems with OFDM signals. As a result of the analysis performed, it can be concluded that communication systems with orthogonal frequency multiplexing provide stable communication in the presence of errors in the communication channel at the $P_{\text {error prob }}=1 \times 10^{-5}$ level.

As the experience of the practical operation of communication systems shows, the best quality level of the channel was achieved at the $P_{\text {error }}$ rob $=1 \times 10^{-10}$ level. Based on the above, the system of inequalities, which will describe the change of operating $\sigma$ modes of the communication system

$$
\sigma=\left\{\begin{array}{l}
\sigma_{1} \text { at } 10^{-5} \leq P_{\text {error } O F D M} \leq 10^{-7} . \\
\sigma_{2} \text { at } 10^{-8} \leq P_{\text {error } S E F D M} \leq 10^{-10}
\end{array}\right.
$$

4. Evaluation of the influence of interference for each of the operation modes (action 6.7 and 10 in the Fig. 2).

After a general assessment of the quality of the communication channel, to develop measures for improving energy efficiency, it is necessary to conduct an additional assessment of the quality of the communication channel. One of the key requirements for such an assessment is acceptable computational complexity [11].

It is proposed to use the methodology developed [11] without reference to the quality of the communication channel.

5. Selection of the optimal channel parameters for each of the modes (steps 8, 9 in the Fig. 2).

The regime change is not a panacea for increasing the efficiency of systems. Therefore, for each of the modes of the communication facility operation, the selection of the optimal set of parameters should be carried out for maximum use of the available radio resource. The optimization problem for solving this problem is given in the following expression

$$
\left\{\begin{array}{l}
\beta_{E}=F_{1}\left(v_{\mathrm{i}}, \Delta F, M, n, R, d, P_{c}, N_{A}, Q_{i}^{2}, \sigma\right) \rightarrow \max \\
v_{i}=F_{2}\left(M, R, N_{A}, \Delta F, d, Q_{i}^{2}, \sigma\right) \geq v_{i p r o b}
\end{array}\right.
$$

where $M$ is the dimension of the signal ensemble, $R$ is the correction code rate $(R=k / n), k$ is the number of information bits in a code combination of length $n, N_{A}$ is the number of active subcarriers channel, $d$ is the code distance value, $\Delta F$ is the channel frequency band, $P_{\mathrm{s}}$ is the signal power, $v_{i}$ is the channel transfer rate, $Q_{i}^{2}$ is the signal-to-noise ratio on each of the subcarriers.

Let's separately dwell on the consideration of the choice of the number of subcarriers in the frequency range available for the operation. The selection of the number of subcarriers is directly related to the compression ratio of spectral-effective signals and is selected depending on the following parameters:

Doppler spectrum dispersion;

the minimum delay time of the rays (multiply reflected copies of the signal);

maximum possible symbol duration (channel coherence time).

Through the Doppler scattering, as well as errors in estimating the frequency of the transmitter at the receiving side, the signal frequency is shifted.

In a number of researches were carried out that the equivalent loss in the required signal-to-noise ratio for a given Doppler scattering, as well as on the error in estimating the carrier at the reception [4]. For shortwave (SW) and ultrashort-wave (USW) communication channels with an equivalent loss in terms of signal/interference not more than $0.5 \mathrm{~dB}$, Doppler spreading should not exceed $2-3 \%$ of the distance between the subcarrier. A frequency offset of $7-8 \%$ of the distance between the subcarrier results in an equivalent decrease in the signal-to-interference ratio of the order of $1 \mathrm{~dB}$. After determining the minimum distance between the subcarrier, the duration of the $T_{c}=1 / \Delta F$ symbol can be calculated.

The minimum delay time between the beams determines the degree of irregularity of the amplitudefrequency characteristic (AFC) of the channel. So, a greater delay between the beams corresponds to a longer period of non-uniformity of the AFC frequency response. With a maximum delay between the rays of 4 $\mathrm{ms}$, the period of non-uniformity of the AFC frequency response is $250 \mathrm{~Hz}$. Thus, the distance between the subcarriers should be selected on the assumption that the AFC frequency response on each of them will be a channel with additive white Gaussian noise (AWGN). Accordingly, the distance between the subcarriers should be significantly less than the period of uneven frequency response of the AFC channel. That is, from this point of view, the distance between the subcarrier should be minimized.

For an SW channel, a distance of $50 \mathrm{~Hz}$ is the maximum allowed, since large values of the distance between the carriers cause a significant distortion of the channel parameters, resulting in increased distortion of the symbol [1-4]. Another limitation on the duration of a symbol is the assumption that the channel parameters must be constant for the duration of the symbol.

This makes it possible to use a simple method for estimating and compensating the AFC frequency response of a channel in the frequency domain on each symbol. Restrictions on the duration of a character in the SW range can be taken in the order of hundreds of milliseconds. The determination of the number of the $N$ subcarriers should be based on the information (technical) speed of the group signal, taking into account the necessary reservation of the part of the channel capacity for various overhead information.

Also, one of the important parameters of the channel is signal-code constructions. In the overwhelming majority of cases, it is possible to distinguish several possible states of the communication channel $[2,4]$. These types of scenarios can correspond to 
different types of signal-code constructions, which are advisable to choose based on the efficiency parameters of radio communications at various levels of signal fading with SEFDM in the communication channel.

The rational parameters of the signal-code constructions for different levels of signal fading and intentional interference in the subchannel are selected at the design stage. Optimization of the considered variant in terms of speed at a limited average signal power at the channel input is reduced to taking into account the strategy of electronic suppression system, optimal subchannel splitting into groups with the same speed, optimal choice of positionality of signals with the $M$ positional quadrature amplitude modulation (QAM- $M$ ) and $M$ positional phase modulation $(\mathrm{PM}-M)$ and the minimum size $d$ in them. In the channels with a low signal-to-interference ratio, the use of turbo codes is the most effective [1-11].

6. Verification of requirements for the noise immunity of the communication channel (step 11 in the Fig. 2).

In this action, the state of the communication channel is checked to those requirements that are put forward to the information that is currently being transmitted through the channel. In the case of meeting the requirements of the channel, the information that is transmitted through it, then the packet is transmitted. If a discrepancy is detected, the packet is also transmitted and a management team is formed to carry out the adjustment of the channel parameters and/or change the mode of operation of the communication device, which will significantly reduce the decision time for subsequent correction of the operation mode (parameters) of the communication device.

We will assess the effectiveness of the proposed method. Evaluation of the effectiveness of the proposed methods in comparison with the known was carried out with the following parameters of communication:

Transmitter power - $1 \mathrm{~W}$;

$10 \mathrm{MHz}$ bandwidth;

The number of subcarriers - 52;

Radiation frequency - $5 \mathrm{GHz}$;

Signal type - 4 position phase shift keying;

Type of correction codes - turbo codes.

Fig. 3 shows the dependence of the signal-to-noise ratio on the bit error probability for the known methods that use spectrally effective signals and the proposed method.

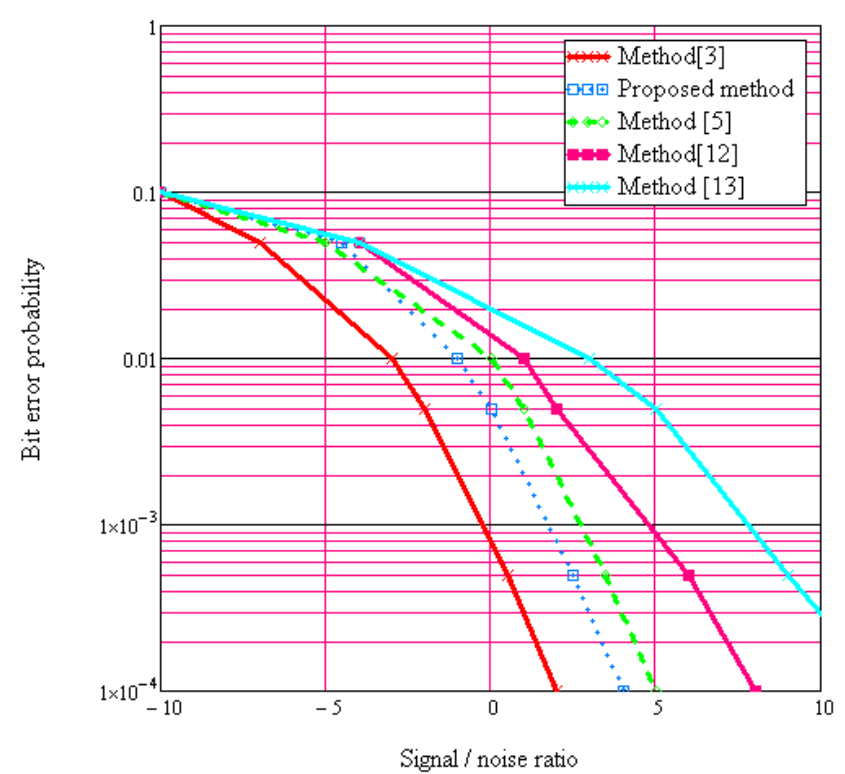

Fig. 3. Comparison of known methods with the proposed

From the graph in Fig. 2, we can conclude that the proposed method provides $15-18 \%$ more noise immunity compared to the known methods of generating spectral-effective signals, but $10-12 \%$ less noise immunity compared to orthogonal signals.

\section{Conclusions}

This article has developed a technique for improving the noise immunity of communication systems.

The essence of this method consists in switching the modes of communication equipment in a session mode depending on the signal-interfering situation with the subsequent adjustment of the quality of the communication channel due to the optimal choice of signal-code structures.

A distinctive feature of this method from the known, which determines its novelty are:

- the possibility of changing the mode of operation in the communication mode;

- the modes of the method operation are signals with orthogonal frequency multiplexing and spectraleffective signals.

The direction of further research should be considered the development of methods for predicting the state of the communication channel using neural networks.

\section{REFERENCES}

1. Shyshatskyi, A.V., Lyutov, V. V., Boroznyuk, M.V. and Rubtsov, I.Yu (2016), "Mathematical model of signal distortion in radio communication systems with orthogonal frequency multiplexing under the influence of deliberate disturbances", Information processing systems, No. 3, pp. 181-186.

2. Slyusar V.I. (2010), "A processing of OFDM signals from UAV on digital antenna array of base station in conditions of jammers", Information Systems Technology Panel Symposium (IST-091/RSY-021) "Information Assurance and Cyber Defence", Antalya, Turkey, 26-27 April 2010.

3. Shyshatskyi, A.V (2015), "Method of formation of signal-code structures of an OFDM signal under the conditions of deliberate interference and selective fading", Information processing systems, No.7 (132), pp. 71-77.

4. Shyshatskyi, A.V., Zhuk, O.G. and Lyutov, V.V. (2015), "Conducting analysis of directions for increasing the efficiency of radio communication systems with orthogonal frequency multiplexing", Armament and military equipment, No. 4(9), pp. 35-40.

5. Slyusar, V.I. and Smolyar, V.G. (2004), "Method of non-orthogonal discrete frequency modulation of signals for narrowband communication channels", Proceedings of higher educational institutions. Radio electronics, Vol. 47, No. 4, pp. 53-59, available at: radio.kpi.ua/article/view/S0021347004040089. 
6. Slyusar, V.I., Vasiliev, K.A., (2008), "Potential boundaries of the frequency multiplexing of N-OFDM signals based on Hartley basis functions", Proceedings of higher educational institutions. Radio electronics, Vol. 51, No. 3, pp. 21-27, available at: radio.kpi.ua/article/view/S0021347008030035.

7. Rainnie, D., Feng, Y., Bajcsy, J. (2015), "On capacity merits of spectrally efficient FDM", Military Communications Conference MILCOM 2015, pp. 581-586.

8. Kalantaievska, S., Pievtsov, H., Kuvshynov, O., Shyshatskyi, A., Yarosh, S., Gatsenko, S., Zubrytskyi, H., Zhyvotovskyi, R., Petruk, S. and Zuiko, V. (2018), "Method of integral estimation of channel state in the multiantenna radio communication systems”, Eastern-European Journal of Enterprise Technologies, Vol 5, No 9 (95), pp 60-76, DOI: https://doi.org/10.15587/1729-4061.2018.144085.

9. Banket, V.L. (2009). Signal code designs in telecommunication systems, Fenix, Odessa, 180 p.

10. Kuvshynov, O.V., Gursky, T.G. and Radzivilov, G.D (2009), "Ensuring the noise immunity of the radio link with the use of OFDM technology under the influence of organized noise", Communication, No. 1, pp. 66-69.

11. Shyshatskyi, A.V., Zhuk, O.G., Lyutov, V.V. and Zhyvotovskyi, R.M. (2016), "An improved method for evaluating the signal parameters with digital modulation types", Science and Technology of the Air Forces of the Armed Forces of Ukraine, No 4 (25), pp. 117-121.

12. Zavjalov, S.V., Makarov, S.B., Volvenko, S.V. and Balashova, A.A. (2015), "Efficiency of coherent detection algorithms nonorthogonal multifrequency signals based on modified decision diagram", 15-th International Conference on NextGeneration Wired/Wireless Advanced Networks and Systems (NEW2AN 2015) and 8th Conference on Internet of Things and Smart Spaces (ruSMART 2015), pp 599-604.

13. Ahmed, S., Darwazeh, I. (2011), "Inverse discrete Fourier transform-discrete Fourier transform techniques for generating and receiving spectrally efficient frequency division multiplexing signals". American Journal of Engineering and Applied Sciences, Vol. 4, pp. 598-606.

Надійшла (received) 30.01.2019

Прийнята до друку (accepted for publication) 13.03.2019

\section{Методика підвищення завадозахищеності систем зв'язку}

\section{Касім Аббуд Махді}

На даний час у зв'язку спостерігається жорсткий дефіцит радіоресурсу систем зв'язку, який викликаний збільшенням кількості абонентів систем стільникового зв'язку, зростанням попиту на інформаційні ресурси, що в свою чергу призводить до пошуку нових технологічних підходів до ії вирішення. Проведений в статті аналіз відомих наукових праць показав, що технологія ортогонального частотного мультиплексування фактично повністю вичерпала можливість свого поліпшення. Одним із шляхів підвищення ефективності використання радіоресурсу систем зв'язку $є$ перехід до використання спектрально-ефективних сигналів. В даній статті проведено розробку методики підвищення завадозахищеності систем зв'язку. Сутність даної методики полягає в перемиканні режимів роботи засобів зв'язку в режимі ведення сеансу зв'язку в залежності від сигнально-завадової обстановки в каналі, 3 подальшим корегуванням параметрів каналу зв'язку за рахунок вибору оптимальних сигнально-кодових конструкцій. В ході проведеного дослідження були використані основні положення теорії зв'язку, теорії сигнально-кодових конструкцій, теорії завадозахищеності, а також загальнонаукові методи, такі як аналіз і синтез. Відмінними особливостями даної методики від відомих, що визначають її новизну, є такі: можливість зміни режиму роботи в режимі сеансу зв'язку; режимами роботи даної методики є сигнали з ортогональним частотним мультипексуванням і спектрально-ефективні сигнали. Запропонована методика забезпечує на 15-18\% більшу завадозахищеність в порівнянні з відомими методиками формування спектральноефективних сигналів, але на 10-12\% меншу завадозахищеність в порівнянні з ортогональними сигналами.

Ключові слова: система зв'язку; радіоресурс; завадозахищеність; спектрально-ефективні сигнали; ортогональне частотне мультиплексування.

\section{Методика повышения помехозащищённости систем связи Касим Аббуд Махди}

В данное время в связи наблюдается жесткий дефицит радиоресурса систем связи, который вызван увеличением количества абонентов систем сотовой связи, ростом спроса на информационные ресурсы, что в свою очередь приводит к поиску новых технологических подходов к её решению. Проведённый в статье анализ известных научных трудов показал, что технология ортогонального частотного мультиплексирования фактически полностью исчерпала возможность своего улучшения. Одним из путей повышения эффективности использования радиоресурса систем связи является переход к использованию спектрально-эффективных сигналов. В данной статье проведена разработка методики повышения помехозащищённости систем связи. Сущность данной методики состоит в переключении режимов работы средств связи в режиме сеанса связи в зависимости от сигнально-помеховой обстановки в канале, с последующей корректировкой параметров канала связи за счёт выбора оптимальных сигнально-кодовых конструкций. В ходе проведённого исследования были использованы основные положения теории связи, теории сигнально-кодовых конструкций, теории помехозащищённости, а также общенаучные методы, такие как анализ и синтез. Отличительной особенностью данной методики от известных, что определяет её новизну, является возможность смены режима работы в режиме сеанса связи. Режимами работы данной методики есть сигналы с ортогональным частотным мультиплексированием и спектрально-эффективные сигналы. Предложенная методика обеспечивает на 15-18\% большую помехозащищённость по сравнению с известными методиками формирования спектрально-эффективных сигналов, но на 10-12\% меньшую помехозащищённость по сравнению с ортогональными сигналами.

Ключевые слова: система связи; радиоресурс; помехозащищённость; спектрально-эффективные сигналы; ортогональное частотное мультиплексирование. 